\title{
Morphology Group Identifier
}

National Cancer Institute

\section{Source}

National Cancer Institute. Morphology Group Identifier. NCI Thesaurus. Code C117602.

A character or string that represents a morphology findings group. 